\title{
Relevant Study on New Opportunities for Expansion of Foreign Investment in China Brought by International Financial Crisis
}

\author{
Fumei Yan \\ Oriental College, Shandong University of Finance and Economics, Tai'an, Shandong, 250100, China
}

Key words: International financial crisis, Expansion of foreign investment, New opportunities.

\begin{abstract}
While making a great impact on the construction and development of Chinese economic society, the occurrence of international financial crisis has produced certain positive influence on the expansion of foreign investment in China and brought new development opportunities to the expansion of foreign investment. This paper analyzes the influence of international financial crisis on the expansion of foreign investment in China, explores the main direction for the expansion of foreign investment in China in the future based on new opportunities and expects to promote better development of Chinese economic society.
\end{abstract}

\section{Introduction}

With gradual strengthening of the trend of world economic integration construction in recent years, the development pace of Chinese enterprises going out has gradually accelerated and foreign investment work has developed rapidly. Especially after the occurrence of international financial crisis, the construction of Chinese economic society has gradually entered a new development stage under the influence of new changes of world economic pattern, which brought new opportunities and challenges to the going-out and further expansion of foreign investment of Chinese enterprises to a certain extent. Therefore, enterprises should adhere to the principle of mutual benefit and win-win idea, take reasonable measures to support the going-out and expansion of foreign investment of China based on the positive influence of international financial crisis in the development process under the current social background, and then realize full use of overseas scientific and technological resources, network information resources and energy and impel Chinese enterprises to make substantive progress in the construction and development process.

\section{Opportunities to going-out and expansion of foreign investment of China brought by international financial crisis}

After the occurrence of international financial crisis, world economic environment has changed greatly and Chinese economic development has transformed periodically, which impelled enterprises to adhere to the development strategy of going out in construction work, further expand foreign investment and realize joint development through mutual benefit to a certain extent.

First, the occurrence of international financial crisis has brought historic development opportunities to the expansion of foreign investment and the acquisition of foreign famous enterprises and brands by Chinese enterprises. The occurrence of international financial crisis has promoted global economic recession and even made transnational corporations in some developed countries get into development dilemma. The existence of this economic environment caused some transnational corporations to conduct organic shrinkage of overseas investment in the development process and even sell some famous brand enterprises on the verge of bankruptcy. This provided relatively wide space for international development of Chinese enterprises. Chinese enterprises could obtain a lot of 
high-quality assets, enterprise brands and advanced technologies and equipment through merger in the environment of international economic crisis. It was a historic development opportunity for enterprises. The acquisition of Hummer and Saab respectively by Tengzhong and Beijing Automobile Group shows to a certain extent that Chinese enterprises have grasped market opportunities in the environment of international economic crisis, realized organic integration of resources through cross-border merger and significantly improved their international competitiveness.

Second, the existence of international financial crisis provided certain historic development opportunities for the expansion of foreign investment of Chinese enterprises. After the occurrence of financial crisis, international market demands gradually weakened and the price of energy resources fell greatly after rise. International transnational corporations had to shrink investment in the development process under the influence of external investment environment. The existence of this phenomenon has laid a foundation for the going-out and expansion of foreign investment of Chinese enterprises, which facilitated the effective development of overseas resources and energy and the establishment of relatively reliable overseas energy resources supply development base by Chinese enterprises and provided historic opportunities for international development of enterprises ${ }^{[1]}$.Relevant Chinese enterprises have grasped development opportunities under international economic crisis in the development process, fully excavated overseas energy resources in an organized, purposeful and planned way, constructed large quantities of important projects in oil, natural gas, iron ore and bauxite development on the basis of strengthening overseas cooperation and laid a solid foundation for the establishment of overseas energy resources supply base while maintaining the security of energy in China.

Third, the existence of international financial crisis has brought new development opportunities for Chinese bank financial institutions to go out and expand foreign investment and conduct transnational operation. The occurrence of international financial crisis has produced serious adverse influence on the construction of financial system in developed countries. Under the influence of financial crisis, most financial institutions in developed countries suffered great asset losses, got into dilemma of their operation and development and had inadequate volume of business. However, the sag of financial market in developed countries has brought new opportunities to internationalized development of bank financial institutions in China and impelled them to implement going-out strategies positively and further expand foreign investment. They have achieved new development in the new period. In the current stage, financial institutions in China such as banks and insurance companies have gradually stepped into the period of rapid development. International financial crisis had relatively small influence on Chinese financial institutions. Therefore, Chinese financial institutions such as banks have grasped opportunities, further expanded foreign investment and positively expanded transnational operational business based on the sag of overseas financial market under the influence of international financial crisis, gradually developed into financial institutions with certain international influence and impelled Chinese financial industry to realize more stable development.

\section{Main development direction of expansion of foreign investment in China in the next stage}

Chinese enterprises should grasp opportunities under the influence of international financial crisis, continue to go out and expand foreign investment, adapt to changes of economic environment and domestic economic construction demands in the development, take corresponding construction measures in the following fields and make certain progress in the next period

\section{Government sectors support and guide relevant enterprises to establish corresponding technical research and development center and marketing system overseas}

In the current stage, though Chinese enterprises have obtained certain development opportunities under international financial crisis, the lack of new-tech products with intellectual property and the 
incompleteness of overseas marketing network restrict the transformation development of relevant Chinese industries to a certain extent, and are important factors causing the long-term position of Chinese economic construction in low section of international division of work and low economic benefit of foreign trade export. Therefore, it is required to guide relevant large enterprises and high-tech enterprises to adhere to development strategies of going out in a purposeful way, establish corresponding scientific and technology research and development center and high- and new-tech industry in regions with intensive scientific and technological resources, guarantee full use of overseas resources, actually develop new technologies and products with independent intellectual property and positively establish a complete overseas marketing network in the process of economic construction so as to impel relevant industrial chain of China to gradually transform towards high value-added marketing work from low value-added processing and manufacturing link and guarantee great economic benefit in the process of participating in global competition while improving the international competitiveness of China.

\section{Positively encourage enterprises with excess domestic production capacity to shift towards overseas}

In the current stage, Chinese manufacturing industry has the problem of excess production capacity in the development process, which has certain adverse influence on industry development. Therefore, in order to positively encourage relevant industries to adhere to the development strategy of going out and further expand foreign investment, it is required to drive the export of relevant parts and components manufacturing, gradually solve the problem of idle large equipment in some industries, appropriately drive the economic development of the host country and promote synergetic development of both countries comprehensively while solving the problem of excess domestic production capacity ${ }^{[2]}$.For example, for energy processing industries with excess domestic production capacity and raw materials imported such as steel industry, government sectors can support and encourage enterprises with certain international competitiveness to set up factories in developing countries such as Latin America and Africa, shift part production capacity outside, positively promote energy conservation and emission reduction on the basis of alleviating the status of excess domestic production capacity, reduce production costs of enterprises and impel them to realize more stable development in the next period.

\section{Expand the development of overseas energy resources in a planned, purposeful and organized way}

Though China has vast territory and abundant resources, it has a large population and insufficient per capita occupancy of resources and important energy resources such as oil and iron ore must be imported in a large quantity. With the development of Chinese economic society and the updating of urban construction, domestic resource consumption has further increased and demands for overseas energy have also increased. To realize sustainable and stable development on this basis, Chinese relevant industries should adhere to the development strategy of going out under the opportunity of international financial crisis, further expand foreign investment with multiple methods, gradually establish relatively stable energy resource supply base overseas and create good conditions for enterprise development and domestic economic construction in China. Chinese government sectors should carry out diplomatic activities positively to effectively improve multilateral economic and trade cooperation, create good market economic environment for enterprise development overseas, establish scientific plans to assist enterprises in overseas energy resource development and impel enterprises to achieve greater development results in the next period.

\section{Further improve internationalized development of financial institutions such as banks and insurance companies}

With the in-depth development of Chinese reform and opening-up in recent years, China has started to participate in the competition of world market positively through industrial transfer of relevant 
overseas industries, low-cost labor force and the introduction of foreign advanced technologies. There have been enterprises transforming and upgrading into large transnational enterprises constantly. China has also developed into a worldwide manufacturing power. With the good development of economic society, the transformation and upgrading step of Chinese industries has gradually accelerated. They play a vital role in the process of participating in international division of work and international competition. More and more manufacturing enterprises have been impelled to further expand foreign investment under the influence of going-out development strategies of the state and establish a relatively complete business network. The construction of economic society has achieved certain development results. Under this economic background, China should also further accelerate the reform of financial institutions such as banks and insurance enterprises, expand overseas business and provide corresponding overseas financial services for the development of Chinese manufacturing, and then comprehensively promote overseas development step of Chinese enterprises, gradually transform the international status of China as manufacturing power and impel China to transform towards the direction of economic and financial power.

\section{Specific measures for supporting relevant Chinese enterprises to go out and expand foreign investment}

While going out to further expand foreign investment and organize the implementation of corresponding multilateral operational activities in the development process, relevant Chinese enterprises will inevitably face greater difficulties and risks of operation. Therefore, enterprises can provide scientific guidance for practical activities of management and impel relevant Chinese enterprises to realize steady operation in overseas market only by establishing scientific operating management concepts based on current operating management demands.

\section{Enterprises should establish mutual-benefit and win-win operating ideas based on opportunities of international financial crisis}

With the improvement of economic entity and the strengthening of international influence, world economic pattern has changed and impelled international benefit distribution pattern of China to be adjusted correspondingly to a certain extent. China has gradually improved its economic power and stepped into the list of world power ${ }^{[4]}$.Some countries in the world have increasingly kept an alert mind towards China on this basis. Therefore, enterprises should adhere to the idea of cooperation, mutual benefit and win-win and actually realize joint development with the host country no matter they choose to invest and set up factories in relevant departments overseas or undertake relevant engineering projects overseas in the process of adhering to going-out development strategies.

\section{Provide certain support for the expansion of foreign investment by enterprises in strict accordance with common international rules}

In the process of adhering to going-out development strategies, enterprises should not only take certain economic development measures from business perspective, but also fully analyze international investment rules, guarantee that they can strictly abide by common international rules and local laws and regulations of the host country in the process of foreign investment, meanwhile follow local manners and customs appropriately, develop harmoniously with economic construction of the host country, promote its economic progress while promoting enterprise development and create conditions for the improvement of international competitiveness of China ${ }^{[5]}$.

\section{Effectively avoid foreign investment risks and facilitate overseas investment work}

In the process of adhering to foreign investment, enterprises should appropriately avoid risks of foreign investment, simplify examination and approval formalities of foreign investment appropriately, adhere to implement foreign investment registration system strictly, further loosen restrictive conditions such as external loan and overseas financing and establish guarantee 
mechanism in risk avoidance and investment security in key regions with overseas investment, e.g. guide enterprises to sign investment protection agreement appropriately in the development process and conduct personnel property security guarantee, risk evaluation and information release work. In this way, enterprises can actually grasp development opportunities under international financial crisis; overseas investment work can achieve good development results; international competitiveness of enterprises can further improve and the international position of China can be further improved.

\section{Conclusion}

In conclusion, the occurrence of international financial crisis has brought new development opportunities to further expansion of foreign investment of China. Therefore, in order to achieve lasting and stable development under this social background, relevant enterprises should analyze the influence of internationalized construction of Chinese enterprises based on international financial crisis, then establish reasonable development strategies, implement going-out strategies and expand foreign investment based on corresponding opportunities obtained by expansion of foreign investment and impel relevant Chinese enterprises to improve their international competitiveness greatly on the basis of fully using overseas energy resources.

\section{References}

[1] Xia Yu, Shang Wencheng. "After Effect" of Financial Crisis and Strategic Choice of Foreign Investment of China. Research on Financial and Economic Problems. 2011(8):54-59.

[2] Huang Lihao. Empirical Study on Relationship of RMB Internationalization and Foreign Investment of China. Shanxi University of Finance and Economics, 2013.

[3] Fang Yini. Changes of Foreign Direct Investment of China after International Financial Crisis and Countermeasures. Journal of Xi'an Institute of Finance and Economics, 2014(6):34-38.

[4] E Libin. Foreign Investment Strategy Game of Chinese Enterprises from Perspective of Transfer Pricing. Mathematics in Practice and Theory, 2013,43(5):65-72.

[5] Shen Lu. Changes of International Balance of Payment of China and Adjustment Measures after USA Financial Crisis and European Debt Crisis. Foreign Trade, 2014(9):98-99. 